\title{
CAUSES AND REMEDIES FOR FILAMENTOUS FOAMING IN ACTIVATED SLUDGE TREATMENT PLANT
}

\author{
PAL P. ${ }^{1}$ \\ KHAIRNAR K.,* \\ PAUNIKAR W.N. ${ }^{2}$
}

\author{
${ }^{1}$ School of Environment and Earth Science \\ North Maharashtra University, Jalgaon, Maharashtra, India \\ ${ }^{2}$ Environmental Virology Cell \\ Council for Scientific and Industrial Research, - Institute (CSIR-NEERI) \\ Nehru Marg, Nagpur, Maharashtra,India
}

Received: $22 / 10 / 2013$

Accepted: 07/10/2014

Available online: 09/10/2014

\begin{abstract}
This paper reviews the problem of foaming associated with the activated sludge process and its control using various physical, chemical and biological methods. Activated sludge process is widely used for treatment of every type of wastewater like industrial, domestic and municipal wastewater. This process is driven by a complex microbial population, among which some mycolic acid containing bacteria leads to the stable foam formation which ultimately results in poor efficiency of the plants and leading to major environmental, operational, and health problems. A number of researches provide the evidences of foaming in wastewater treatment plants and its control using physical, chemical and biological methods. Current approaches for controlling foam includes operational adjustments, additional structures, controlling dissolved oxygen levels, water sprays, steam application, polymer addition, chlorination and a novel and ecofriendly approach that is treatment of filamentous bacteria with the specific phages. A detailed study of all methods is presented and collectively described in this review paper for a better understanding of the foam controlling strategies.
\end{abstract}

Keywords: Filamentous Bulking, Selectors, Mycolata, Actinobacteria, Foaming.

\section{Introduction}

Although the activated sludge process has been the most commonly used technology for treating both domestic and industrial wastewaters, its stable operation is still plagued by sludge bulking or foaming (Martins et al., 2011; Petrovski et al., 2011).

Activated sludge process is a common aerobic treatment use to reduce the amount of organic matter from wastewater by using microorganisms. The microorganisms growing in aeration tanks use to convert dissolved organic matter into their own biomass. ASP depends on the profound balance ecosystem among the bacterial communities present in sludge, viz; Aeromonas, Achromobacter, Alcaligenes, Bacillus, Flavobacterium, Micrococcus and Pseudomonas, Thiobacillus, Acinetobacter, nitrifying organisms; Nitrosomonas and Nitrobacter (Hughes and Stafford, 1976; Lightharst and Oglesby, 1989; Pick, 1995).

In this review the most common operating problems in ASP and their controlling strategies are discussed. Main problems related to ASP are sludge bulking, Pin-floc/deflocculation, foaming (biological) and rising solids (denitrification). Among the large number of different filamentous microorganisms 
reported in the literature only a few such as Microthrix parvicella, Nostocoida limicola, Nocardia spp., Type $021 \mathrm{~N}$ and Type 0041 of the Eikelboom species have been repeatedly cited with bulking and foaming problems (Wanner et al., 1998; Ovez et al., 2006). Filamentous bacteria are important component of ASP as low levels of filaments are required for settling of solids in a healthy activated sludge. As the bacterial population rises in the sludge it usually leads to the formation of brown viscous sticky foam (Liu et al., 2003).

The thick scum layer is formed on the surface of settling sludge by mycolic acid producing filamentous bacteria and this can lead to various operational problems (Jenkins et al., 2003). Wastewater composition is one of the significant factors affecting foam formation, as it has been found that slowly degradable organic material and lipids favors the growth of both $M$. parvicella and G. amarae (Jenkins et al., 2003, Mamais et al., 1998). Richard (1989) postulated that the operation of an activated sludge system at sludge ages of greater than $10 \mathrm{~d}$ promotes $M$. parvicella growth and thus stimulates filamentous bulking and foaming problems. Based on full- and laboratory-scale experiments Knoop and Kunst, (1998), suggested that occurrence of foaming problems generally appears in wastewater treatment plants operating at low temperatures $\left(<15{ }^{\circ} \mathrm{C}\right)$ with a sludge loading rate of less than $0.1 \mathrm{kgBOD} 5 / \mathrm{kgSS} / \mathrm{d}$.

Filamentous bulking and foaming can be controlled by various specific and nonspecific strategies. Specific control strategies are preferable as they are selective and offer a permanent solution of the problem whereas non-specific methods tend to provide only temporary solutions. Noutsopoulos et al. (2006), based on laboratory scale studies has shown that reduction of sludge age may prove to be an efficient method to suppress $M$. parvicella growth. Sludge age reduction method cannot be applied in activated sludge systems that need to nitrify throughout the year, because the sludge age required to washout M. parvicella, may also eliminate nitrifying bacteria.

Non-specific methods like, use of oxidizing chemicals are currently the only available strategies for effective foaming control and it can be applied in all WWTP. However, use of high chlorine doses may inhibit both nitrification and organic matter removal and cause floc break-up (Mamais et al., 2011). Therefore, based on evidence provided by microbiological observations by Ovez and Orhan (2007), it can be concluded that chlorine remediation of foaming provide only temporary and superficial way for the treatment of wastewater containing oil and grease. Gordonia spp. still remains intact inside the floc even after the chlorine application and maintains its potential for excessive growth (Ovez et al., 2006). Higher aeration basin temperature provides favorable conditions for the growth of Nocardia while $M$. parvicella grows at lower temperatures. Due to the physical interlocking of the filaments in the foam provides stability to the foam and this type of foam is difficult to remove by antifoam chemicals. Nocardia and M.parvicella bacteria are tolerant to chlorine and are found within the flocs so, high chlorine dosages required for this type of foam control (Jenkins et al., 1993).

A number of researches provide the information of foaming in wastewater treatment plants and its control using physical, chemical and biological methods. Here, the objective of this review paper is, a detailed and collective study of foam controlling methods and their comparison. The collective study leads to better understanding of cause of foaming and its controlling strategies. We tried to find out the best suitable and ecofriendly approach for foaming control in waste water treatment plant (WWTP).

\section{Causes of foaming}

Foaming and bulking problems in ASPs are associated with the presence of a variety of filamentous bacteria along with that parameters have been identified as the causative agents of filamentous bulking and foaming. In situ, filamentous bacteria, Sphaerotilus spp. and Leptothrix spp. Microthrix parvicella, Corynebacterium, Dietzia, Gordonia, Skermania, Mycobacterium, Nocardia, Rhodococcus, and Tsukamurella (Goodfellow and Maldonado, 2006) are the key organic degraders and offer the skeletal matrix for the formation of compact flocs. The wastewater containing slowly degradable organic material like lipids, proteins, and fats being preferably utilized by filamentous microorganisms 
specifically by M. parvicella and G.amarae which are responsible for foaming (Jenkins et al., 1993; Ovez et al., 2006). Substrate in the form of long chain fatty acids at low temperatures favors the growth of M. parvicella (Mamais et al., 1998). The discharge received by the sludge treatment plants from oil refineries and food processing facilities which contains oil and grease, experiencing long standing Nocardia problems (Shao et al., 1997). The foaming organisms having mycolic acid containing hydrophobic cell surface (Lemmer H., 1986) and ability of the production of extracellular polymers (Khan and Forster, 1988) which collectively responsible for bubble stabilization in presence of air and wastewater, and cause foaming (Withey et al., 2005). Filamentous bacteria have a structure similar to that of fats, oils and grease. Due to the property of water repelling they float on the surface of liquid in aeration tank. The foaming organisms can attach to the hydrophobic substrates of fats, oils and greases and use to grow by consuming them as a food source. While, non-hydrophobic bacteria unable to attach the hydrophobic substrates (Griffiths, 2010). Pagilla et al., (2002) investigated the biosurfactant production capability of filamentous bacteria and concluded that soluble acetate and soluble hexadecane are used as carbon sources by the bacteria for their growth and biosurfactant production. The research confirms that the foaming problems in activated sludge containing $G$. amarae is due to the biosurfactant production in presence of hydrophobic substrates such as hexadecane. In absence of foaming organisms at ASPs small, white globules of fats and grease can be seen on the surface of the secondary clarifiers. These globules emerge in the effluent and difficult to remove even by surface skimmers. Foaming organisms are the essential part of the treatment process as they are playing a treatment role by breaking down fats, oils and greases (Griffiths, 2010). The conclusion made by Griffiths (2010) is, it is more important to manage filamentous bacteria not to remove them.

Petrovski et al., (2011a) suggested that, for formation of stable foam three components are required, air bubbles, surfactants and hydrophobic cells. Addition of surfactant converted a scumming population into one forming stable foam. The above three components are provided by the aeration, compounds present in the wastewater and surfactant production by the filamentous bacteria (Pagilla et al., 2002) and foaming bacterial cells respectively. If anyone of the three is absent, stable foam is difficult to produce for example unstable foam will generate with non-hydrophobic cells, and a greasy surface scum is formed by the cells in absence of surfactants while addition of surfactants can convert a scumming population into one forming a stable foam (Petrovski et al., 2011). The role of surfactants in foaming is poorly understood, but evidence is presented for the first time that surfactin synthesized by Bacillus subtilis may be important (Petrovski et al., 2011a). Although the foaming bacteria grow faster on fatty, oily substances, they still grow relatively slowly as the fats, greases and oils are difficult to digest (Griffiths, 2010). It is suggested that the percentage of excessive bulking incidents is $10 \%$ to $29 \%$ for a SRT of greater than $8.5 \mathrm{~d}$ and filamentous bacteria requires a minimum sludge age of 10 days to grow and form a stable population (Griffiths, 2010) whereas there is no bulking occurs for SRTs of lower than $7 \mathrm{~d}$ (Noutsopoulos et al., 2006). Most early ASPs were focusing only on the biochemical oxygen demand (removal of organics) and operated at relatively short sludge ages of maximum 3 to 4 days. Now-a-days in order to remove the nutrients from wastewater effluents ASPs are maintained the sludge ages of 10 days or more. The reason for longer sludge age is to permit nitrification and denitrification (Griffiths, 2010). The presence of unfavorable conditions in the activated sludge system, such as toxic conditions ( $\mathrm{pH}$ below 6.5 or above 9.0), insufficient DO, nutrient deficiencies, or seasonal (winter/summer) temperatures ultimately lead to the foaming problem. Subsequent pollution of the clarifier effluent with suspended solids has a negative impact on plant productivity and efficiency (Withey et al., 2005).

\section{Filamentous foaming control methods}

\subsection{Non Specific Methods}

Foaming due to filamentous organisms and the dispersion of gas bubbles that creates a dense brown scum layer on the surface of activated sludge basins and secondary clarifiers. To control or reduce the 
harmful effect of the foam, various physical methods have been used since a long time. Mainly used methods are given below:

- Operational adjustments, (e.g. decreasing mean cell residence time) (Noutsopoulos et al., 2006)

- additional structures (e.g. classifying selectors) (Chudoba et al., 1973; Caravelli et al., 2003)

- controlling dissolved oxygen levels in the pre-oxidation reactor (Pasinetti et al., 2005)

- non-specific measures such as water sprays, steam application (Noutsopoulos et al., 2006).

\subsubsection{Mean cell residence time}

Mean cell retention time (MCRT), also sometimes called mean cell residence time, is a parameter that describes the average time in days that microorganisms stay in an activated sludge process. Noutsopoulos et al., 2006 in one of their studies have shown that reduction of sludge age is an efficient method to suppress $M$. parvicella growth. The most used control method for foaming is to reduce the system's MCRT. MCRT reduction between 8 and 10 days controls the growth of M. parvicella can often be controlled by reducing MCRT reduction to $<8$ days. On the other hand for Nocardia control, ASP have to reduce the MCRT to <3 days (Jenkins et al., 1993). However, this method is less successful in reducing foaming in full scale wastewater treatment plants. If nitrification is not required, gradually increase the $\mathrm{F} / \mathrm{M}$ ratio and decrease the MCRT but it is undesirable and difficult to apply when long retention times are required for nitrification and other processes.

\subsubsection{Use of selectors}

The term "classifying selector" coined in the early nineties by Brown and Caldwell. A selector is a mixing basin or channel where RAS and influent wastes mix prior to the aeration basin. It is the mechanism of selection of floc forming organisms against the foam causing microbes. As foam causing organisms are enriched into the solids in the foam so, their rapid removal controls their population to low levels in the mixed liquor.

A selector is a tank or compartment in which some of the water parameters like F/M ratio, electron acceptor can be manipulated to provide the conditions to prevent the overgrowth of undesirable filamentous microorganisms. The selector tank is fixed prior to the aeration basin for mixing the RAS (with the seeds of all type of microbial population) and incoming wastewater under the desired conditions for $15-30$ minute contact time and aerated to achieve $70-80 \%$ removal of soluble BOD $_{5}$ through the selector (Jenkins et al., 1993) then the mixture is passed to the aeration basin. There are three categories of biological selectors: anoxic, aerobic and anaerobic.

\subsubsection{Anoxic selectors}

An anoxic condition is defined as the absence of oxygen and the presence of nitrate as the electron acceptor.

\subsubsection{Aerobic selectors}

Aerobic selector can control Nocardia populations at an MCRT of 5 days (Bitton, 2005).

\subsubsection{Anaerobic Selectors}

Anaerobic conditions suppress the growth of filamentous bacteria such as Sphaerotilus natans and type $021 \mathrm{~N}$.

The best approach is to try several selector sizes, using a larger basin or channel with movable baffles or exit gates and bypass around the selector to achieve the same objectives and operator's control over the selector. According to Ayers and Kelly (2012), classifying selectors are most cost effective long-term solution for controlling Microthrix bacteria.

Although the use of selectors has proven sound but due to challenges of removal of a difficult material from the aeration tanks, still classifying selectors have limitation for foam reduction (Parker et al., 2003). 


\subsubsection{Thermal hydrolysis}

Thermal hydrolysis of secondary scum to control biological foam by Cambi process is very effective as well as financially viable technique for the control of foaming. This process shows promising results for biological foam control in wastewater treatment plants where solids retention time control and selective wasting cannot be applied and selector installation is not possible. An initial cost comparison of thermal hydrolysis and several widely accepted foam-management strategies shows it to be competitive; however, optimization of operating pressure and temperature is necessary for thermal hydrolysis (Jolis and Marneri, 2006).

\subsubsection{Steam application}

Hoyle et al., (2006) experimented at lab scale for showing the results of steam application for reduction of foam causing organisms. The steam from a steam generator or boiler (with water pump and piping attachments) is delivered to the reactor vessel with 0.5 liter of foam sample. Samples with Pressure and time combinations (treatments), ranging from 30 to 70 psig and 10 to 60 minutes of exposure time were tested. Samples, before and after treatment, were Gram-stained and filament abundance was determined (Hoyle et al, 2006). Table 1. below showing the results of Hoyle's experiments.

Table 1. Steam application observed the following results. Hoyle et al., 2006)

\begin{tabular}{cccl}
\hline $\begin{array}{c}\text { Foam } \\
\text { Sample(liter) }\end{array}$ & $\begin{array}{c}\text { Time of treatment } \\
(\mathbf{m i n})\end{array}$ & Pressure (psig) & \multicolumn{1}{c}{ Observation } \\
\hline 0.5 & Untreated samples & - & $\begin{array}{l}\text { Right-angled, branched, Gram- } \\
\text { positive filamentous bacteria } \\
\text { (nocardioforms) were abundant }\end{array}$ \\
\hline 0.5 & $60 \mathrm{~min}$ & $>40 \mathrm{psi}$ & $\begin{array}{l}\text { Lowest nocardioform abundance } \\
0.5\end{array}$ \\
\hline & $40 \mathrm{~min}$ & $50 \mathrm{psi}$ & $\begin{array}{l}\text { nocardioform destruction, } \\
\text { branched chains have been } \\
\text { converted to rods. }\end{array}$ \\
\hline 0.5 & Not specified & $70 \mathrm{psi}$ & lowest nocardioform abundance \\
\hline
\end{tabular}

The microscopic analysis also revealed some cell destruction and branched chains have been converted to rods while some Gram-positive, non-nocardioform filaments appeared to be resistant to steam. It is also concluded in a paper that, steam application has the potential for destroying the cell structure of nocardia form filaments present in foam. The facilities where the equipment for steam production is available and subsequent downstream solids handling facilities, such as anaerobic digestion, can use the steam application for foam reduction with high success (Hoyle et al., 2006).

\subsubsection{Skimming System}

Skimming system should be a part of activated sludge system so that the layer of foam can be removed from the upper side of aeration tank not more than 1 to $3 \mathrm{~cm}$ deep. The skimming system should be positioned at proper locations where forward momentum in the reactor and the floating material will flow to the central position (E.g. exit end of aeration basins or location where natural baffling occurs).The effectiveness of the skimming system may be augmented by placing surface baffles to encourage the movement of material at the surface of the liquid toward the foam removal weir(s) (Parker et al., 2003).

\subsubsection{Use of water sprays}

The use of water sprays do help in the fight with foam if properly positioned in the right spots. A sprinkler on the aeration basin may be fitted. Water sprays are of two types: Submerged and surface overflows - It is difficult to get rid of foam using Submerged aeration basin gates which can contain 
foam from exiting to the secondary clarifier while Surface overflows out of the aeration basin can help get foam to the secondary clarifier and then skimmed off the surface.

\subsubsection{Pump Inlet System}

The pump is used to remove materials on the liquid surface and pump it to the plant wasting system. The design of the skimming sump must be integrated with the control of the pumping equipment, which must allow the removal of floating materials, suction break and prevent vortex formation. Various types of pumps like submersible solids handling, column type solids handling, positive displacement diaphragm type are available depending upon their specific application, capacity, ability to pass liquid with entrained air, and to be able to break suction in the sump without damage. There must be some control devices to detect liquid levels accurately. Some ultrasonic and capacitance type devices are used for this purpose. For the centrifugal type of pump, decreasing motor amps or closure of the discharge check valve can be used. It terminates the operation for when the sump empties (Parker et al., 2003)

\subsection{Chemical methods}

Treatment of many chemicals are given to the WWTP for the control of foaming and foam causing microorganisms. Till now, no method is $100 \%$ efficient to overcome this problem. Chlorination is one of the most popular applications for the rapid and effective control of activated sludge bulking and foaming. Three common chlorine addition points are: (1) into the RAS stream at a point of turbulence (elbows in pipes; into the volute or discharge of RAS pumps; and into and below the liquid level in a riser tube of an airlift RAS pump); (2) directly into the final clarifier center well or feed channel; and (3) in an installed side stream where the MLSS is pumped from and returned to the aeration basin.

Chlorine addition to the RAS line(s) is the method of choice and most generally successful but, chlorine addition to the aeration basin does not work and only causes floc dispersion and system damage. Mamais et al., (2011), have shown the efficiency of the following coagulants: ferric chloride, ferrous chloride, polyaluminium chloride, hydrated aluminium sulphate, cationic polymer in bench scale batch experiments and in addition to that ammonia uptake rate (AUR) and oxygen uptake rate (OUR) measurements also conducted to evaluate the toxic effects of the most promising coagulants on nitrification and organic matter removal. Ramakrishna and Viraraghavan (2005), reported that for chlorination excess sludge is treated with chlorine and the chlorinate sludge is returned to the aeration tank. Chlorine usually disrupts the cell wall structure of microorganisms and affects their metabolic functions. Neethling et al., (1987) suggested that during chlorination with the destruction of filamentous bacteria, floc formers should not be affected as they helps in the sludge settling. The effect of chlorine dose and period has been investigated in many studies. Ramirez et al., (2000) studied the effect of chlorine dosage in the range of 4 to $8 \mathrm{~g} / \mathrm{kg}$ VSS/ day on one of the filamentous bacteria Type $021 \mathrm{~N}$, and observed a significant SVI reduction after 10 days and a $90 \%$ decay of the same microorganism after 22 days. Ferrous Chloride is an effective coagulant and defoamer based on bivalent iron ( $\left.\mathrm{Fe}^{2+}\right)$. It is used primarily to control hydrogen sulfide formation to reduce odor and corrosion, and for phosphorus removal applications. Mamais et al., (2011) given that a significant foaming control can be achieved on addition of high doses of ferrous and ferric chloride, equal to approximately $32.5 \mathrm{Fe} 2+\mathrm{kg}-1 \mathrm{MLSS}$ and $29.9 \mathrm{Fe} 3+\mathrm{kg}-1 \mathrm{MLSS}$, respectively. At lower concentration only $50 \%$ or less reduction of sludge foaming potential is achieved (Mamais et al., 2011). According to Neethling et al., (1987) chlorination is usually started with a dosage lower than $5.0 \mathrm{mg} / \mathrm{L}$ and gradually reaches $35 \mathrm{mg} / \mathrm{L}$ while the most effective chlorine level is in the range of $1-15 \mathrm{mg} / \mathrm{L}$ (Jenkins et al., 1993). It is investigated that Polyaluminium chloride (PAX) and cationic polymer are the most efficient among all the coagulants however low foaming control efficiency may also obtained with aluminium sulphate addition. With the reduction of foaming potential, Polyaluminium chloride (PAX) addition also helps in the improvement of settling properties of activated sludge in a particular amount of 6.6-11.5 g Al3+ kg-1 MLSS. The microscopic analysis of sludge samples proved that after PAX or polymer addition, flocs appeared more compact and dense (Mamais et al., 2011). 
Chemical treatment such as polymer addition proved to be very effective for the control of filamentous bacteria because PAX addition caused no inhibition on autotrophic and heterotrophic bacteria that perform nitrification and organic carbon removal, respectively. Improvement in flocculation and increase of flocs size in activated sludge is achieved by the addition of PAX and cationic polymer because the above chemicals changes the morphological characteristics of M. parvicella and Gordona amarae filamentous organisms probably due to the neutralization of negative surface charged particles by the addition of positively charged coagulants (Mamais et al., 2011). Additionally, biosurfactants that are produced by filamentous bacteria (Pagilla et al., 2002) and negatively charged anionic surfactants are responsible for foam stabilisation (Petrovski et al., 2011a). Positively charged flocculation agents may add to the influent water to minimize their foam stabilizing effect by neutralizing these surfactants (Mamais et al., 2011). Overall positive effects of the above chemical treatment is that it improves the flocculation as well as helps in the removal of filamentous microorganisms which are embedded within the flocs and removed in the form of excess sludge.

In more recent studies it has shown that the compound 3 hydroxyhexadecanoic acid (IFB4) selectively inhibit the growth of mycolata without affecting autotrophic nitrification (Davenport et al., 2005). Mamais et al., (2011) concluded that polyaluminium chloride (PAX) and cationic polymer are the most efficient among all the coagulants investigated. PAX addition is reported to decrease the activity of exoenzymes such as lipase, due to which bacteria lost its ability to use lipids as the energy sources. PAX addition for foaming control in an activated sludge system improves the flocculation and partially inhibit substrate uptake by filamentous organisms especially M.parvicella (Mamais et al., 1998). $75-100 \%$ reduction of the sludge foaming potential can be achieved by PAX or polymer addition, at the specified doses as summarized in the Table no. 2 .

Table 2. Showing the chemicals and their concentrations effectively control the foaming (Mamais et al., 2011)

\begin{tabular}{cccl}
\hline S.No. & Name of chemical & Concentration required & \multicolumn{1}{c}{ Advantage } \\
\hline 1 & $\begin{array}{c}\text { Polyaluminium chloride } \\
\text { (PAX) }\end{array}$ & $6.6-11.5 \mathrm{~g} \mathrm{Al3}+\mathrm{kg}-1 \mathrm{MLSS}$ & $\begin{array}{l}\text { Improved settling property } 75-100 \\
\% \text { reduction of the sludge foaming } \\
\text { potential }\end{array}$ \\
\hline 2 & Cationic polymer & 3.5 to $4.5 \mathrm{~g} \mathrm{kg-1} \mathrm{MLSS}$ & $\begin{array}{l}\text { High foaming control, } 75-100 \% \\
\text { reduction of the sludge foaming } \\
\text { potential }\end{array}$ \\
\hline 3 & ferrous chloride & $32.5 \mathrm{Fe} 2+\mathrm{kg}-1 \mathrm{MLSS}$ and & Foam control $>50 \%$ \\
\hline 4 & Ferric chloride & $29.9 \mathrm{Fe} 3+\mathrm{kg}-1 \mathrm{MLSS}$ & Foam control $>50 \%$ \\
\hline
\end{tabular}

\subsubsection{Disadvantages of using Chemicals}

Along with the advantages of using chemicals for the reduction of foam their demerits can also be seen due to which, chemical treatment needs a perfection and controlled use. Some negative effects of chemical treatment are given below:

1. Soluble COD is increase due to the chlorination treatment in the effluent as well as it is responsible for poor sludge settleability. These potential problems can be minimized by the use of membrane separation units instead of conventional sedimentation tanks (Ramakrishna and Viraraghavan, 2005).

2. Another principal disadvantage of chlorination is the formation of undesirable chlorinated byproducts when raw water reacts with the chlorine (Saby et al., 2002).

3. Previous research found that when the raw water is reacted with chlorine, the yield of trihalomethanes (THMs) increased as a function of the amount of chlorine input (Liu, 2003). 
4. For the effective sludge treatment process the autotrophic and heterotrophic bacteria with the floc former should not be effected by the addition of chemicals. In many cases chlorination causes floc break-up due to the high chlorine doses and may inhibit both nitrification and organic matter removal (Mamais et al., 2011)

5. Dosing chemicals such as $\mathrm{NaClO}$ and $(\mathrm{SO} 4)_{3} \mathrm{Al}_{2}$ are unsuccessful due to the short term effectiveness (Pasinetti et al., 2005).

6. RAS chlorination is not more useful for the control of Nocardia as it is favored at higher aeration basin temperature and physically interlocked in the foam. To overcome the Nocardia problem high dose of chlorine is required which may destroy the activated sludge floc and negatively effect the settling characterstics of the sludge (Jenkins et al., 1993).

7. It was observed to exert a total destruction of the filamentous texture between the flocs, leaving only a lot of loose and chopped filament fragments with resulting turbidity in the bulk solution (Ovez et al., 2006).

\subsection{Specific Microbiological Methods}

As we have seen above physical and chemical methods for the control of foaming on the temporary basis. Currently, the control and prevention of foaming is difficult, and there is a need for novel approaches (De los Reyes, 2010; Soddell et al., 1990). One potentially attractive control strategy is, to reduce mycolata cell numbers in the mixed liquor below the foaming threshold value by applying suitable lytic phages (Thomas et al., 2002; Withey et al., 2005). Although most studies have shown that, chemical methods are mostly use for the reduction of foam but one possible attractive approach for controlling these foam-stabilizing organisms is the use of specific bacteriophages, which only affects the foam causing bacteria leaving others unaffected. In activated sludge systems hydrophobic Actinobacteria are commonly associated with the stabilization of foams. However, the process for reduction of foam by these bacteriophages is unknown but various studies have shown the effectivity of bacteriophages against the filamentous bacteria at laboratory scale. Genome characterization of various filamentous bacteriophages are now available.

Some novel polyvalent DNA phages GTE2 (Petrovski et al., 2011b) ,GTE7 (Petrovski et al., 2011c), TPA2 (Petrovski et al., 2011d) and other 17 (Thomas et al., 2002) are isolated from activated sludge of wastewater treatment plant and genome characterization of GTE2, GTE7, TPA2 described by Petrovski (2011b; c; d). This is confirmed by doing Transmission electron microscopy (TEM) that the isolated phage belongs to family Siphoviridae. The phages GTE2 and GTE7 was screened for their ability to lyse 65 different mycolata strains and concluded that phage GTE7 is effective against more species of filamentous bacteria than phage GTE2. The Phage GTE2 is lytic for Gordonia terrae, Rhodococcus globerulus, Rhodococcus erythropolis, Nocardia otitidiscaviarum, and Nocardia brasiliensis (Petrovski et al., 2011b) while GTE7 is potentially more attractive as a biocontrol agent for Foaming because of its ability to lyse a wider range of mycolata species (Petrovski et al., 2011c). GTE2 may prove useful in the field as a biocontrol agent as it shows promising results in controlling stable foam production by its host bacteria under laboratory conditions (Petrovski et al., 2011b). This approach is environmentally safe and offers the ability to target the foam-stabilizing filamentous bacterial strains specifically without affecting the other important bacterial populations required for the floc formation, nitrification and other biological process for the treatment of wastewater (Withey et al., 2005). Hatfull et al., (2006; 2008) given that other phages which target the Mycobacteria are available, while a very little has been published on actinobacterial phages. Although phages lytic for Rhodococcus (Summer et al., 2011), Tsukamurella (Petrovski et al., 2011d), Gordonia (Petrovski et al., 2011c) were described in recent researches. Now, characterization and genome sequences of various phages namely GTE2, GTE5, GTE7, TPA2 (Petrovski, 2011) are available which may be very helpful for control of stable foaming in WWTP. Thomas et al., (2002) isolated 17 phages from activated sludge which was specific for members of the mycolic acid containing bacteria which cause a sticky foaming in ASP, 12 of which could propagate on members of more than one genus. So, this approach may effectively controls the foaming problem but its full scale application is not largely given yet. 


\section{Conclusion}

On the basis of present study it can be concluded that various physical, chemical, biological methods are available for the control of foaming but all the practices are leading to some of the disadvantages which ultimately causing problem to the activated sludge process and takes a higher cost for their maintenance. For applying the physical treatment methods, a proper set up is required which is not possible for every treatment plants especially for those which are using conventional methods. Chemical treatment is somewhat beneficial but the cost of chemicals is very high and frequent use of high amount of chemicals, other processes of the plants like nitrification and removal of phosphates may also be affected. After studying the above three methods it can be concluded that biological treatment is novel and ecofriendly approach for the foam control and it must be applied to the full scale Wastewater treatment plant (WWTP). Various bacteriophages against mycolatas and their genome sequences are now available, which may be helpful for further studies to know their effectiveness on the filamentous bacteria of different WWTP. Bacteriohages can be applied to the plants after growing in the laboratory in high concentration or different approaches may be use for the application of phages to the WWTP.

- After isolation of bacteriophages and their detailed study at laboratory scale may prove to be helpful in application of bacteriophages at large scale.

- By identifying specific phage by the operator will lead to counter specifically only the foam forming bacteria without affecting the other bacteria.

- The microbial analysis of the system is a prerequisite to phage application as the bacterial population may vary between (WWTP).

- Only narrow host range bacteria should apply to the plant otherwise broader host range phage could lead to the degradation of useful bacteria.

Once the phage is introduced to the plant that will remain in the plant and will provide provides a safe, environmentally sound effective means of reducing offending filamentous bacteria.

\section{References}

Ayers D. and Kelly R. (2012), Solutions to Mitigate Effects of Microthrix parvicella at the Meridian WWTP, PNCWA Annual Conference 2012.

Bitton G. (2005), Wastewater Microbiology, Third Edition, a John Wiley \& sons, inc., Publication, pp 288.

Caravelli A., Contreras E.M., Giannuzzi L. and Zaritzky N. (2003), Modeling of chlorine effect on floc forming and filamentous micro-organisms of activated sludges, Water Research, 37, 2097-2105.

Chudoba J., Grau P. and Ottova V. (1973), Control of activated sludge filamentous bulking II: selection of microorganisms by means of a selector, Water Research, 7, 1389-1406.

Davenport R.J., Ballinger S.J., Minnikin D.E. and Sallis P.J. (2005), The selective inhibition of mycolata to control foam while maintaining nitrification in an activated sludge plant, Conference Paper - WEFTEC Conference 2005.

De los Reyes F.L. (2010) Foaming. In: R. J. Seviour and P. H. Nielsen (ed.), Microbial ecology of activated sludge. IWA Publishing, London, United Kingdom, pp. 215-259.

Goodfellow M. and Maldonado L.A. (2006), The families Dietziaceae, Gordoniaceae, Nocardiaceae and Tsukamurellaceae, In: M. Dworkin, S. Flakow, E. Rosenberg, K.-H. Schleifer, and E. Stackebrandt (ed.), The prokaryotes: archaea. Bacteria: firmicutes, actinomycetes. Springer, New York, N, pp. 843-888.

Griffiths P. (2010), Foaming organisms in sewage treatment friend or foe: victim of bad publicity, paper presented on 35th Annual Qld Water Industry Operations Workshop Community Sports Centre, CQ University, Rockhampton."

Hatfull G.F., Cresawn S.G. and Hendrix R.W. (2008), Comparative genomics of the mycobacteriophages: insights into bacteriophage evolution, Res. Microbiol., 159, 332-339. 
Hatfull G.F., Pedulla M.L., Jacobs-Sera D., Cichon P.M., Foley A., Ford M.E., Gonda R.M., Houtz J.M., Hryckowian A.J., Kelchner V.A., Namburi S., Pajcini K.V., Popovich M.G., Schleicher D.T., Simanek B.Z., Smith A.L., Zdanowicz G.M., Kumar V., Peebles C.L., Jacobs W.R., Jr, Lawrence J.G. and Hendrix R.W. (2006), Exploring the mycobacteriophage metaproteome: phage genomics as an educational platform, PLoS Genet., 2, e92.

Hoyle L.E., Pitt P.A., Stone A.L. and de los Reyes III F.L. (2006) Investigating steam application for reducing foaming in activated sludge systems, WEFTEC conference 2006, 10, 321-330.

Hughes D.E. and Stafford D.A. (1976) The Microbiology of the Activated Sludge Process, CRC Reviews in Environmental Control, PP: 233."

Jenkins D., Richard M.G. and Daigger G.T. (1993), Manual on the causes and control of activated sludge bulking and foaming, 2nd Edition, Lewis Publishers, USA"

Jenkins D., Richard M.G. and Daigger G.T. (2003), Manual on the causes and control of activated sludge bulking foaming and other solids separation problems, Third edition, Lewis Publishers, Boca Roton.

Jolis D. and Marneri M. (2006) Thermal hydrolysis of secondary scum for control of biological foam, Water Environment Research, 78, 835-841.

Khan A.R. and Forster C.F. (1988), Biosurfactant production by Rhodococcus rubra, Environ. Technol., 9, 1349-1360.

Knoop S. and Kunst S. (1998) Influence of temperature and sludge loading on activated sludge settling, especially on Microthrix parvicella, Wat. Sci. Tech., 37, 27-37.

Lemmer H. (1986), The ecology of scum causing actinomycetes in sewage treatment plants, Water Research, 20, 531-535.

Lightharst B. and Oglesby R.T. (1989), Bacteriology of an Activated sludge wastewater treatment plant. A Guide to Methodology, Journal of Water Pollution Control Federation, 41, 267-281.

Liu Y. (2003), Chemically reduced excess sludge production in the activated sludge process, Chemosphere, 50, 1-7.

Mamais D., Andreadakis A., Noutsopoulos C. and Kalergis C. (1998), Causes of and control strategies for Microthrix parvicella bulking and foaming in nutrient removal activated sludge systems, Wat. Sci. Tech., 37, 9-17.

Mamais D., Kalaitzi E. and Andreadakis A. (2011), Foaming control in activated sludge treatment plants by coagulants addition, Global NEST Journal, 13, 237-245.

Martins A.M., Karahan O. and van Loosdrecht M.C. (2011), Effect of polymeric substrate on sludge settleability, Water Research, 45, 263-273.

Neethling J.B., Chung Y.C. and Jenkins D. (1987), Activated sludge chlorine reactions during bulking control, J. Env. Eng. Div. Amer. Soc. Civil Eng., 113, $134-145$.

Noutsopoulos C., Mamais D. and Andreadakis A. (2006), Effect of solids retention time on Microthrix parvicella growth, Water SA, 32.

Ovez S. and Orhon D. (2007) Microbial Ecology of Bulking and Foaming Activated Sludge Treating Tannery Wastewater, J. Env. Sci. Health, Part A, 40, 409-422.

Ovez S., Ors C., Murat S. and Orhon D. (2006), Effect of hypochloride on microbial ecology of bulking and foaming activated sludge treatment for tannery wastewater, J. Env. Sci. Health, Part A, 41, 2163-2174.

Pagilla K.R., Sood A. and Kim H. (2002), Gordonia (nocardia) amarae foaming due to biosurfactant production, Wat.Sci.Tech., 46, 519-524.

Parker D., Geary S., Jones G., Mclntyre L., Oppenheim S., Pedregon V., Pope R., Richards T., Voigt C., Volpe G., Willis J. and Witzgall R. (2003), Making classifying selectors work for foam control in the activated sludge process, Water Environment Research, 75, 83-91.

Pasinetti E., Emondi V. and Peroni M. (2005), In situ test for biological foam removal, Conference Paper - WEFTEC Conference 2005."

Petrovski S., Dyson Z.A., Quill E.S., Mcllroy S.J., Tillett D. and Seviour R.J. (2011a), An examination of the mechanisms for stable foam formation in activated sludge systems, Water Research, 45, 2146-2154.

Petrovski S., Robert J., Seviour R.J. and Tillett D. (2011b), Characterization of the genome of the polyvalent lytic Bacteriophage GTE2, which has potential for biocontrol of Gordonia, Rhodococcus, and Nocardia-stabilized foams in activated sludge plants, Appl. Environ. Microbiol., 77, 3923-3929. 
Petrovski S., Robert J., Seviour R.J. and Tillett D. (2011c), Prevention of Gordonia and Nocardia stabilized foam formation by using bacteriophage GTE7, Appl. Environ. Microbiol., 77, 7864-7867.

Petrovski S., Seviour R.J. and Tillett D. (2011d) Genome sequence and characterization of the Tsukamurella phage TPA2, Appl. Environ. Microbiol., 77, 1389-1398.

Pick E.B. (1995), Aerobic bacteria, In: Ecological aspects of used-water treatment. Eds: Cruds, CR and awkes HA, Vol.1, Academic press.

Ramakrishna D.M. and Viraraghavan T. (2005) Strategies for sludge minimization in activated sludge process - A Review, Fresenius Environmental Bulletin, 14, 2-12.

Ramirez G.W., Alonso J.L., Villanueva A., Guardino R., Basiero J.A., Bernecer I. and Morenilla J.J. (2000), A rapid, direct method for assessing chlorine effect on filamentous bacteria in activated sludge, Water Research, 34, 3894-3898.

Richard M.G. (1989), Activated Sludge Microbiology, Water Environment Federation, Alexandria, VA, pp. 73.

Saby S., Djafer M. and Chen G.H. (2002), Feasibility of using a chlorination step to reduce excess sludge in activated sludge process, Water Research, 36, 656-666.

Shao Y.J. and Konstadinas K. (1997), Nocardia foaming controlling method of wastewater treatment. Patent US 5614098 A."

Soddell J.A. and Seviour R.J. (1990), Microbiology of foaming in activated sludge plants-a review, J. Applied Bacteriology, 69, 145-176."

Summer E.J., Liu M., Gill J.J., Grant M., Chan-Cortes T.N., Ferguson L., Janes C., Lange K., Bertoli M., Moore C., Orchard R.C., Cohen N.D. and Young R. (2011), Genomic and functional analyses of Rhodococcus equi phages ReqiPepy6, ReqiPoco6, ReqiPine5, and ReqiDocB7, Appl. Environ. Microbiol., 77, 669-683."

Thomas J.A., Soddell J.A. and Kurtboke D.I. (2002)m Fighting foam with phages?, Wat.Sci.Tech., 46, 511-518."

Wanner J., Ruzickova I., Jetmarova P., Krhutkova O. and Paraniakova J. (1998), A national survey of activated sludge separation problems in the Czech Republic: Filaments, floc characteristics and activated sludge metabolic properties, Wat.Sci.Tech., 37, 271-279.

Withey S., Cartmell E., Avery L.M. and Stephenson T. (2005), Bacteriophages- potential for application in wastewater treatment processes, Science of Total Environment, 339, 1-18. 